\title{
HUKUM TIDAK TUNGGAL: POTRET PLURALISME HUKUM DALAM PENGATURAN KAWASAN TEMPAT SUCI PURA ULUWATU DI BALI
}

\author{
Oleh: \\ I Putu Sastra Wibawa \\ Program Studi Hukum Agama Hindu, \\ Fakultas Ilmu Agama dan Kebudayaan, \\ Universitas Hindu Indonesia Denpasar \\ sastra@unhi.ac.id
}

\begin{abstract}
The research is titled 'Law is not single: portrait of legal pluralism in the setting of the holy place of Uluwatu Temple in Bali.' Political legal pluralism is a policy approach as a middle ground or intersection in solving the problem of construction difference of holy place of Uluwatu temple in Bali, both from state law in the form of regional regulation concerning spatial plan and area of Bali Province and customary law of Pecatu custom village. Political legal pluralism tries to be an alternative way to unify the elements of state law, ethics / moral / religion, and society in order to achieve the sense of justice of Indigenous Peoples of Pecatu that owns the land that is exposed to the radius of the holy place of Uluwatu Temple. Political legal pluralism is an offer of legal policy based on the values of Pancasila philosophy. The theory used as a knife of analysis is the legal theory of law, as well as the theory of legal pluralism. This research is a qualitative research type, with socio-legal research approach with constructivism paradigm of law and using approach method of legal pluralism. Data source namely primary and secondary data collected by doing elaboration of field study and literature study that in narration with interpretive descriptive data processing.
\end{abstract}

Keywords: Law is not single, Legal Pluralism, Uluwatu Temple

\begin{abstract}
Abstrak
Penelitian ini berjudul 'Hukum tidak tunggal: potret kemajemukan hukum dalam seting tempat suci dari Pura Uluwatu di Bali. Politik pluralisme hukum adalah pendekatan kebijakan sebagai jalan tengah atau persimpangan dalam menyelesaikan masalah perbedaan konstruksi tempat suci Pura Uluwatu di Bali, baik dari hukum negara dalam bentuk peraturan daerah tentang rencana tata ruang dan wilayah Provinsi Bali dan hukum adat desa adat Pecatu. Pluralisme hukum politik berusaha menjadi cara alternatif untuk menyatukan unsur-unsur hukum negara, etika / moral / agama, dan masyarakat dalam rangka mencapai rasa keadilan Masyarakat Adat Pecatu yang memiliki tanah yang terpapar dengan radius tempat suci dari Pura Uluwatu. Pluralisme hukum politik adalah tawaran kebijakan hukum berdasarkan nilai-nilai filsafat Pancasila. Teori yang digunakan sebagai pisau analisis adalah teori hukum hukum, serta teori pluralisme hukum. Penelitian ini merupakan jenis penelitian kualitatif, dengan pendekatan penelitian sosio-legal dengan paradigma konstruktivisme hukum dan menggunakan metode pendekatan pluralisme hukum. Sumber data yaitu data primer dan sekunder dikumpulkan dengan melakukan penjabaran studi lapangan dan studi pustaka yang di narasikan dengan pengolahan data deskriptif interpretatif.
\end{abstract}

Kata kunci: Hukum tidak Tunggal, Pluralisme Hukum, Pura Uluwatu 


\section{PENDAHULUAN}

Pada era globalisasi Pulau Bali dengan berbagai keunikannya mengalami perkembangan pariwisata yang pesat. Perkembangan pariwisata tersebut ternyata selain memberikan kontribusi dalam bentuk terciptanya lapangan kerja dan investasi, namun di sisi lain telah mengakibatkan tingginya migrasi ke Pulau Bali terutama pada wilayah Bali selatan, baik yang berasal dari wilayah Bali maupun luar wilayah Bali. Perkembangan Bali sebagai tujuan pariwisata tidak dapat dilepaskan dengan perkembangan keberadaan daerah tujuan wisata di Bali. Salah satu tujuan wisata di Bali adalah keberadaan Pura Uluwatu termasuk pula kawasan sekitarnya yang telah mengalami dampak yang cukup significant pada sisi pembangunan pariwisata khususnya penataan ruang dan wilayah kawasan Pura Uluwatu.

Sebagai tempat suci umat Hindu Pura Uluwatu berfungsi untuk memuja Tuhan dengan segala manifestasi-Nya. Oleh karena itu, Pura Uluwatu sebagai tempat suci perlu dijaga kesuciannya baik secara niskala (tidak nyata) maupun secara sekala (nyata) sebagai salah satu pura terbesar di Bali dengan status Pura Sad Kahyangan yang terletak di Desa Adat Pecatu, Kecamatan Kuta Selatan, Kabupaten Badung, Bali khususnya menjaga dari gempuran perkembangan pariwisata.

Walaupun perkembangan pariwisata di Bali telah menghasilkan kemajuan dalam berbagai bidang kehidupan, namun pada sisi lain juga telah menimbulkan berbagai masalah pembangunan, yang berimplikasi langsung terhadap daya dukung ruang, seperti: meningkatnya kebutuhan terhadap lahan (baik untuk permukiman maupun kegiatan kepariwisataan), meningkat dan pesatnya alih fungsi lahan pertanian, berkurangnya tutupan vegetasi wilayah, meningkatnya keterpusatan lalu lintas yang mengakibatkan kemacetan lalu lintas, meningkatnya jumlah lahan kritis, menurunnya tingkat pelayanan sarana dan prasarana wilayah, masalah sosial kependudukan dan lapangan kerja, serta memudarnya nilai-nilai budaya (termasuk pula terancamnya nilai kesucian tempat suci) sebagai penanda jati diri masyarakat dan daerah Bali.

Pemerintah Provinsi Bali melakukan upaya pencegahan permasalahan daya dukung ruang di Bali yakni dengan ditetapkannya Peraturan Daerah Provinsi Bali Nomor 16 Tahun 2009 Tentang Rencana Tata Ruang dan Wilayah Provinsi Bali Tahun 2009-2029 (selanjutnya disebut Perda 16/2009). Salah satu menjadi hal yang menarik dalam Perda 16/2009 terkait dengan keberadaan Pura Uluwatu adalah adanya pengaturan tata ruang kawasan tempat suci Pura yang mengadopsi norma agama Hindu yakni Bhisama kawasan suci ${ }^{1}$. Secara singkat dapat dilihat penormaan Bhisama Kesucian Pura pada Pasal 50 ayat (2) Perda 16/ 2009 yang menyatakan Kawasan tempat suci sebagaimana dimaksud dalam Pasal 44 ayat (1) huruf $b$, ditetapkan mengacu Bhisama PHDIP Tahun 1994, dengan kriteria:

a. kawasan tempat suci di sekitar Pura Sad Kahyangan dengan radius sekurangkurangnya apeneleng agung setara 5.000 (lima ribu) meter dari sisi luar tembok penyengker pura;

b. kawasan tempat suci di sekitar Pura Dang Kahyangan dengan radius sekurang-kurangnya apeneleng alit setara dengan 2.000 (dua ribu) meter dari sisi luar tembok penyengker pura; dan

c. kawasan tempat suci di sekitar Pura Kahyangan Tiga dan pura lainnya, dengan radius sekurang-kurangnya Apenimpug atau Apenyengker.

Adanya hukum kawasan tempat suci tersebut berimbas pula pada penataan ruang Pura Uluwatu. Pura Uluwatu karena memiliki status sebagai Pura Sad Kahyangan maka radius tempat suci nya yakni dengan ukuran apaneleng agung yakni setara dengan 5 (lima) kilometer. Artinya kawasan tempat suci yang disucikan dengan radius 5 (lima) kilometer. Terdapat konsekuensi terhadap adanya aturan hukum kawasan tempat suci Pura Uluwatu tersebut, dimana tanah-tanah baik yang dimiliki oleh pemerintah, swasta maupun masyarakat tidak boleh pemanfataanya bertentangan dengan ketentuan tersebut. Pemanfaatan tanah yang 1 Untuk menjaga kesucian pura dari gempuran arus globalisasi dan alih fungsi lahan, Parisada Hindu Dharma Indonesia Pusat (PHDI Pusat) menetapkan Bhisama tentang Kesucian Pura Nomor: 11/Kep/l/ PHDI/1994, pada tanggal 25 Januari 1994 (Selanjutnya disebut Bhisama Kesucian Pura). Dalam Bhisama Kesucian Pura itu membagi radius tempat suci menjadi 3 (tiga) bagian, yakni, apeneleng agung , apeneleng alit, dan apenimpug atau apenyengker. 
terkena radius kawasan suci hanya boleh digunakan yang terkait sarana spiritual keagamaan Hindu saja, dilarang untuk digunakan selain apa yang ditentukan itu, termasuk pula dilarang dalam membangun akomodasi penunjang pariwisata.

Akibat adanya pembatasan pemanfaatan tanah yang terkena dampak radius kawasan suci Pura Uluwatu mendapatkan perlawanan dari masyarakat yang memiliki hak atas tanah yang terkena radius tempat suci. Perlawanan justru datang dari anggota masyarakat Desa Adat Pecatu yang merasa akses keadilan terhadap tanah mereka di batasi. Masyarakat yang terkena dampak menuntut keadilan kepada negara dengan dalih bahwa negara harus menjamin Hak Asasi Manusia khususnya hak atas keadilan dan ekonomi terhadap tanah mereka.

Permasalahan terjadi disebabkan karena Perda 16/2009 sebagai hukum dipandang tidak sesuai dengan realitas hukum lokal yang ada di dalam masyarakat. Hukum sebagai suatu realitas, mengkaji implementasi hukum di masyarakat, hukum menjadi salah satu sub sistem di dalam masyarakat dimana sub-sistem yang lainnya itu, seperti ekonomi, politik, budaya, agama, dll. Dengan demikian, hukum akan sarat akan nilai-nilai yang ada di masyarakat yang tidak bebas dari nilai-nilai kepentingan di dalamnya yang dapat bersifat positif maupun negatif.

Salah satu konsekuensi hukum dalam konteks masyarakat, maka hukum akan selalu dipengaruhi oleh berbagai faktor salah satunya globalisasi. Globalisasi telah merubah masyarakat, termasuk hukumnya pun mengalami perubahan seirama dengan perubahan masyarakat yang mengglobal tersebut. Hukum dalam menata kehidupan berbangsa dan bernegara di Indonesia pada era globalisasi mempunyai peran yang sangat penting. Persoalan akan muncul ketika mendesain hukum di era global yang sesuai dengan nilai dan struktur sosial Indonesia. Sangat diperlukan sikap kritis dan kesediaan berpikir terbuka dan holistic dalam hal ini. Sesuai dengan pemikiran bahwa hukum harus dipikirkan tidak lepas dengan bidang ekonomi, politik, sosial dan budaya ${ }^{2}$ seusai dengan realitas di masyarakat.

\footnotetext{
2 Yusriyadi, Tebaran Pemikiran Kritis Hukum dan Masyarakat, SuryaPenaGemilang, Malang,2009, hIm.54.
}

Hukum dalam realitas masyarakat merupakan suatu sistem yang bekerja saling melengkapi. Meminjam pendapat Lawrence Freidman ${ }^{3}$,menyatakan hukum sebagai suatu sistem terdiri dari struktur sebagai elemen nyata dalam hukum sebagai kerangka badan yang bersifat permanen dalam hal ini terkait dengan struktur pembentuk dan penegak radius kawasan suci Pura Uluwatu. Substansi tersusun dari peraturan-perarturan dan ketentuan bagaimana instansi struktur hukum harus berperilaku terkait dengan pengaturan mengenai radius kawasan suci baik oleh pemerintah maupun masyarakat adat. Sedangkan kultur hukum adalah kekuatan sosial yang terus menerus menggerakkan hukum yang merupakan elemen sikap dan nilai sosial masyarakat terkait dengan kesadaran masyarakat dalam interaksinya terkait radius kawasan suci Pura Uluwatu.

Bentuk perlawanan terhadap ketentuan radius kawasan tempat suci Pura Uluwatu dapat dilihat salah satunya pada perlawanan juga dijalankan oleh perorangan, kelompok dan kesatuan masyarakat hukum adat Desa Adat Pecatu secara yuridis dengan melakukan gugatan hak uji materiil sebanyak 7 (tujuh) kali terhadap Perda 16/2009 ke Mahkamah Agung (MA). Dengan alasan pokok dalam permohonan gugatan karena hilangnya kesempatan mencari penghasilan bagi keluarga mereka masingmasing di atas tanah yang dimilikinya, mengakibatkan turunnya nilai ekonomis tanah tersebut dan juga karena tidak sesuai dengan ukuran kesucian Pura Uluwatu yang berdasarkan adat kebiasaan yang mereka warisi selama ini. Lahirnya gugatan masyarakat karena masyarakat sadar bahwa hukum sebagai bagian sistem hukum adalah intrumen untuk melindungi hak-hak mereka untuk mendapatkan keadilan. Jika hukum tidak melindungi hak mereka, maka mereka selayaknya menggugat hukum itu. ${ }^{4}$ Namun, hasilnya permohonan gugatan itu ditolak melalui Putusan Mahkamah Agung Nomor. 30,31,32,33,34,35,36 P/ HUM/2010 dan Perkara Nomor 65 P/HUM/2013 dengan alasan pokok bahwa Perda tersebut

3 Lawrence M. Freidman, Sistem Hukum Perspektif IImu Sosial, Nusa Media, Bandung, 2009, hlm. 2-17.

4 Sulistyowati Irianto, Akses Keadilan dan Migrasi Global, Kisah Perempuan Indonesia Pekerja Domesik di Uni Emirat Arab, Yayasan Pustaka Obor, Jakarta, 2011, hlm.33. 
tidak bertentangan dengan peraturan perundang-undangan yang lebih tinggi. Adapun uji materiil yang terkait ketentuan kawasan tempat suci Pura Uluwatu dalam Perda 16/2009 dapat dijabarkan secara singkat dibawah ini.

Perlawanan dari masyarakat terhadap Perda 16/2009 jika dicermati disebabkan karena adanya perbedaan kontruksi berpikir mengenai radius kawasan suci antara radius kawasan suci Pura Uluwatu yang ditentukan oleh Pemerintah Provinsi Bali yang mengadopsi Bhisama PHDI yakni seluas 5 (lima) $\mathrm{km}$ dengan persepsi masyarakat adat penyangga Pura Uluwatu yang diatur dalam awig-awig (aturan adat) dengan luas tidak lebih dari 1 (satu) $\mathrm{km}$ yang disebut dengan alas kekeran.

Perbedaan persepsi itu menimbulkan diskursus antara apa yang diyakini oleh Pemerintah melalui Perda 16/2009 dengan apa yang diyakini oleh masyarakat adat mengenai alas kekeran. Meminjam pendapat Habbermas, dalam diskursus tersebut mengharuskan adanya penyingkiran kendala-kendala tindakan, menyingkirkan seluruh motif selain keinginan untuk mencapai kesepakatan rasional dan penangguhan validitas klaim. Konsensus yang dihasilkan karena adanya bukti dan kekuatan argument yang terkandung dalam argumentargumen yang diajukan. ${ }^{5}$

Idealnya pembangunan hukum tata ruang di Bali selain harus memperhatikan kearifan lokal setempat juga harus berbasis pada landasan idiil hukum di Indonesia, yakni nilai-nilai Pancasila yang kemudian dijabarkan dalam bentuk peraturan perundang-undangan, salah satunya dalam bentuk Perda tata ruang dan wilayah di Bali. Terkait dengan upaya membangun hukum tata ruang radius kawasan tempat suci Pura di Bali yang berbasis Pancasila perlu ditekankan bahwa hukum tata ruang kawasan tempat suci Pura hendaknya dibingkai dengan semangat dari ke 5 (lima) nilai-nilai dalam Pancasila. Secara ideal konstruksi hukum tata ruang radius kawasan suci Pura Uluwatu berbasis Pancasila merupakan bagian dalam program Pembangunan Sistem Hukum Pancasila di Indonesia. Peran pemerintah sangat diperlukan dalam mencapai hal tersebut. Sesuai

5 Thomas McCarthy, The Critical Theory of Jurgen Habermas, MIT Press, Massachusetts, 1982, diterjemahkan oleh Nurhadi, Teori Kritis Jurgen Habermas, Kreasi Wacana, Bantul, 2011, hlm.377-378. dengan hakikatnya pemerintah ada dalam rangka untuk tercapainya tujuan bangsa dan negara, ${ }^{6}$ Peranan peraturan perundang-undangan sangat dominan dan esensial karena pada hakikatnya peraturan perundang-undangan adalah seperangkat norma yang mengatur dan memungkinkan negara untuk menjalankan fungsinya dan melindungi warga. ${ }^{7}$

Adanya hubungan yang tidak sinkron antara hukum negara, kearifan lokal masyarakat serta unsur moral, etika, dan agama dalam pengaturan kawasan tempat suci Pura Uluwatu seperti yang telah di uraikan di atas menjadi latar belakang untuk mengangkat judul "Hukum Tidak Tunggal: Potret Pluralisme Hukum dalam Pengaturan Kawasan Tempat Suci Pura Uluwatu di Bali".

1. Prinsip-prinsip politik pluralisme hukum apakah sebagai arahan dalam pengaturan kawasan tempat suci Pura Uluwatu?

Kebaruan (novelty) penelitian dapat dilihat nantinya pada bentuk hubungan yang saling menguatkan antara hukum negara, moral, etika, dan agama, serta masyarakat dalam pengaturan kawasan tempat suci Pura Uluwatu di Bali. Hubungan ke tiga unsur tersebut di bingkai dalam pendekatan pluralisme hukum. Selama ini pengaturan kawasan tempat suci Pura Uluwatu di Bali lebih ditekankan pada pemberlakukan hukum negara (Peraturan Daerah).

Tujuan Khusus penelitian ini sesuai dengan rumusan masalah yang telah di sampaikan di atas, antara lain: 1) untuk mengkaji dan menganalisa landasan yang menjadi dasar perlunya pengaturan kawasan tempat suci Pura Uluwatu berbasis pluralisme hukum, dan 2) untuk mengkaji dan menganalisa prinsipprinsip politik pluralisme hukum yang menjadi arahan dalam pengaturan kawasan tempat suci Pura Uluwatu ke depannya.

Temuan yang ditargetkan dalam penelitian ini, yakni: penggunaan pendekatan pluralisme hukum dalam pengaturan kawasan tempat suci Pura Uluwatu lebih memberikan rasa keadilan bagi masyarakat yang terkena radius kawasan tempat suci Pura Uluwatu. Pendekatan pluralisme hukum menjadi titik tengah antara hukum negara, moral, etika, dan agama serta

6 M.Mas'ud Said, Birokrasi Di Negara Birokratis, UMM Press, Malang, 2007, hlm. 218.

7 S.F. Marbun, dkk, Dimensi-dimensi Pemikiran Hukum AdministrasiNegara, UIIPress, Yogyakarta,2004, hlm.19. 
masyarakat dalam pengaturan kawasan tempat suci Pura Uluwatu. Pengembangan ilmu pengetahuan, khususnya ilmu hukum di titik beratkan pada penggunaan metode sosio-legal reserch, dengan pendekatan pluralisme hukum yang masih jarang digunakan oleh peneliti hukum yang pada umumnya masih banyak berkutat pada aliran positivisme hukum.

\subsection{Tinjauan Pustaka}

Menski ${ }^{8}$ memberikan pemahaman mengenai pentingnya pluralisme hukum untuk memahami hukum dan tertib hukum, hukum di kaji tidak hanya mengkaji norma-norma saja, melainkan juga harus mempertimbangkan nilai-nilai, fakta, makna, proses, struktur, hubungan kekuasaan, personel, dan teknologi. Pluralisme hukum mengembangkan model hukum interaktif antara hukum negara, nilai-nilai/etika/agama dan norma-norma sosio-kultural. Model pluralisme hukum mengedepankan kecairan hukum. Meminjam pemikiran Menski tentang pluralisme hukum tersebut sangat relevan digunakan dalam membahas penelitian yang berjudul Politik Pluralisme Hukum dalam Pengaturan Kawasan Tempat Suci Pura Uluwatu di Bali.

Selain itu, ada beberapa kajian pustaka lainnya yang digunakan sebagai acuan dalam penelitian ini, antara lain:

Kajian dari Sudiarta tahun 2011 dalam Jurnal Masalah-Masalah Hukum yang mengangkat judul Penetapan Kawasan Tempat Suci dan Kawasan Pariwisata dalam Penataan Ruang di Bali. Penelitian ini membahas mengenai adanya tumpang tindih pengaturan mengenai kawasan tempat suci sebagai kawasan lindung, atau bahkan sebagai kawasan pariwisata yang di atur dalam produk hukum daerah. Kontribusi dari kajian Sudiarta terletak pada pemikiran bahwa kawasan tempat suci merupakan kawasan lindung yang harus di jaga kelestariannya. Pengaturan hukum sangat penting dilakukan dalam menjaga kawasan tempat suci tersebut. Namun kajian Sudiarta belum menyentuh pembahasan mengenai adanya perbedaan pengaturan Kawasan Tempat Suci yang di dasari oleh perbedaan kondisi wilayah masing-masing di Bali. Perbedaan pengaturan kawasan tempat suci yang dikaji dalam bingkai pluralisme hukum

\footnotetext{
8 Werner Menski, Perbandingan Hukum dalam Konteks Global, Sistem Eropa, Asia, dan Afrika, Nusa Media, Bandung, 2008, HIm.795
}

dalam penelitian ini belum disentuh oleh Sudiarta.

Selanjutnya, Arniati tahun 2015 dalam Jurnal Dharmasmrti mengangkat judul tentang Bhisama Parisada Tentang Kesucian Pura: Pergulatan Interpretasi Atas Kawasan Suci Pura Uluwatu. Penelitian Arniati tersebut membahas 3 (tiga) hal, yakni: alasan terjadinya pergulatan interpretasi Bhisama Parisada atas Kawasan Tempat Suci Pura Uluwatu, membahas tentang proses terjadinya pergulatan interpretasi Bhisama Parisada atas Kawasan Tempat Suci Pura Uluwatu, dan membahas implikasi pergulatan interpretasi Bhisama Parisada atas Kawasan Tempat Suci Pura Uluwatu. Penelitian Arniati memberikan kontribusi bahwa ditemukan 2 (dua) pengaturan mengenai kawasan tempat suci Pura Uluwatu, namun belum mengangkat isu tentang politik pluralisme hukum sebagai titik tengah atau konsensus terhadap perbedaan pengaturan kawasan tempat suci baik yang di atur oleh negara maupun oleh kearifan lokal masyarakat adat yang nantinya menjadi topic pembahasan dari penelitian yang akan dilakukan ini.

Kajian pustaka selanjutnya dari Sutrisna tahun 2016 dalam Jurnal Lingkungan Binaan yang mengangkat kajian tentang Pelanggaran Bhisama Kesucian Pura di Sekitar Pura Dang Kahyangan di Kecamatan Kuta Selatan, Kabupaten Badung. Penelitian ini mengangkat tentang adanya pelanggaran terhadap radius kesucian Pura akibat perkembangan pariwisata dan ekonomi. Penelitian Sutrisna memberikan kontribusi khususnya pada pemahaman bahwa ternyata perkembangan pariwisata dan ekonomi menjadi salah satu faktor pelanggaran terhadap pengaturan kawasan tempat suci. Namun, penelitian Sutrisna tersebut berbeda dengan penelitian ini yang mengangkat secara khusus tentang politik pluralisme hukum dalam pengaturan kawasan tempat suci Pura Uluwatu. Politik pluralisme yang menjadi jalan keluar agar kawasan tempat suci Pura Uluwatu tetap terjaga kedepannya.

\subsection{Metode Penelitian}

Penelitian ini berjenis penelitian kualitatif. Metode yang digunakan secara khusus adalah deskriptif interpretatif, dengan menggunakan paradigma penelitian konstruktivisme dan pendekatan sosio-legal research. Memokuskan 
topik kajian pada politik pluralisme hukum dalam pengaturan kawasan tempat suci Pura Uluwatu dengan lokasi penelitian di desa adat Pecatu, Kecamatan Kuta Selatan, Kabupaten Badung, Provinsi Bali. Sumber data yakni data primer yang di dapatkan dari melakukan wawancara dan observasi di lapangan, sedangkan data sekunder di dapat dari bahan hukum primer yakni peraturan perundangundangan termasuk di dalamnya Peraturan Daerah No 6 Tahun 2009 tentang Rencana Tata Ruang Wilayah Provinsi Bali Tahun 2009-2029 dan bahan hukum sekunder yakni bahan pustaka berupa buku-buku referensi yang terkait dengan judul penelitian.

Data primer dan sekunder yang telah terkumpul kemudian di olah dengan metode interpretasi hukum, baik secara historis, filosofikal, dan sosiologikal. Setelah dilakukan pengolahan data, kemudian dilakukan penyimpulan data yang mengarah pada penggunaan metode pluralisme hukum.

\section{PEMBAHASAN}

\subsection{Hukum Kawasan Suci Pura Uluwatu di Bali, Hukum yang Tidak Tunggal}

Hukum di era global harus mampu berdiri di tengah-tengah antara kepentingan ekonomi dan kepentingan penguasa dalam menjalankan kekuasaannya ${ }^{9}$ serta kepentingan masyarakat, termasuk menata ruang radius kawasan suci Pura Uluwatu sebagai salah satu destinasi pariwisata di Bali. Hukum sebaiknya dibuat sebagai kontrol dalam kegiatan penataan ruang yang memperhatikan nilai-nilai yang ada. Ke depan hendaknya kontruksi hukum tata ruang radius kawasan suci Pura di Bali berbasis pada nilai-nilai kearifan lokal sesuai dengan desa, kala dan patra setempat dibingkai dengan Pancasila, yakni penataan ruang yang memperhatikan religiusitas suatu wilayah, memperhatikan hak-hak masyarakat setempat terhadap ruang itu, menjamin keberlangsungan

$9 \ldots \ldots . . . .5$ The core elements of both economic and political activity -capital, labour, credit, and money, as well as public or private power and right - are legal institutions. Lawis the link binding centres and peripheries to one another and structuring their interaction........ Lihat, David Kennedy, Leiden Journal of International Law (2013), 26, pp. 7-48 C _Foundation of the Leiden Journal of International Law, 2013, International Legal Theory, Law and the Political Economy of the World http:// journals.cambridge.org, diakses tanggal 14 April 2016. integrasi bangsa dalam penataan ruang, dengan mengedapankan musyawarah jika terjadi perbedaan persepsi untuk mencapai keadilan sosial dalam pemanfaatan ruang. Ini tidak lepas dari tujuan hukum yakni untuk menstabilkan pergaulan hidup, merealisasikan ketertiban dan perdamaian serta mewujudkan keadilan, dimana ada nilai-nilai tertentu yang harus dipegang. ${ }^{10}$

Sehingga, manakala relativitas atau fleksibilitas hukum dapat dipertahankan terkait dalam penataan ruang kawasan tempat suci, setiap individu, kelompok, dan atau institusi merdeka untuk terus secara aktif 'mengkonstruksi' hukum. Maka demokratisasi hukum dapat dijaga, melalui konsensus atau kesepakatan terus terbangun di antara individu, kelompok, dan/atau instansi.

Dengan telah berkurangnya dominasi negara dalam menata kawasan suci Pura Uluwatu dengan memperhatikan kearifan lokal daerah setempat, maka cita-cita negara Indonesia untuk mencapai religius welfarestate tidak mustahil untuk dicapai. Religius welfarestate terkait dengan penataan kawasan suci Pura Uluwatu dapat diartikan, pemerintah menjamin masyarakat untuk menggunakan hak-haknya termasuk hak atas tanah untuk mencapai kesejahteraan bersama dengan tetap mengacu pada nilai-nilai spiritual masyarakat, dalam hal ini nilai spiritual kawasan suci Pura. Dengan kata lain, mencapai kesejahteraan dengan tetap pula menjaga kesucian Pura yang di tata oleh pemerintah dengan tetap memperhatikan kearifan lokal setempat sebagai organ negara yang mempunyai kewenangan dalam hal regulasi. ${ }^{11}$

Integrasinya kearifan lokal, hukum agama dan hukum nasional dalam satu ramuan hukum tata ruang radius kawasan suci Pura Uluwatu dalam teori hukum disebut sebagai pluralisme hukum. Pluralisme hukum akan mengurangi ketegangan antara universalisme dan lokalisme sehingga stabilitas sosial akan tetap terjaga. ${ }^{12}$

10 FX Adji Samekto, Justice Not For All, Kritik terhadap Hukum Modern dalam Perspektif Studi Hukum Kritis, Genta Press, Yogyakarta, 2008, hlm.9 11 Lahirnya kontruksi baru mengenai radius kawasan suci Pura Uluwatu di Bali setidaknya mengurangi ketegangan konstestasi antara Kebangsaan, Religiusitas, dan politik lokal masyarakat 12 ....such regionalism and pluralism alleviate the tension between universalism and localism associated with globalization and improve social stability throughout 
Pluralisme adalah konsep hukum yang isinya lebih dari satu prinsip dan substansi hukum, serta melihat dari situasi dengan perbedaan keadaan fakta sosial yang ada. ${ }^{13}$ pluralisme hukum negara (state legal pluralism) seperti disebut Gordon Woodman ${ }^{14}$, atau pluralism hukum yang lemah (weak legal pluralism) seperti disebut John Griffiths ${ }^{15}$. Pluralisme hukum negara (state legal pluralism) muncul manakala hukum negara sebagian berasal dari batang tubuh norma yang sejak awalnya memang dibentuk sebagai hukum negara dan sebagaiannya lagi berasal dari norma-norma non-negara yang diakui hukum negara, seperti hukum adat dan agama.

Dengan demikian, dasar politik pluralism hukum dalam pengaturan kawasan suci Pura Uluwatu di Bali berangkat dari persepsi bahwa hukum yang berlaku di Bali khususnya yang menyangkut pengaturan kawasan suci Pura Uluwatu merupakan hukum yang tidak tunggal. Artinya, di Bali hegemoni hukum Negara melalui Peraturan daerah tentang Tata Ruang dan Wilayah Provinsi Bali yang di dalamnya mengatur pula kawasan tempat suci Pura Uluwatu yang berbasisi nilai-nilai agama Hindu dalam Bhisama ternyata mendapatpertentangan

the world...Lihat James D.fry, Pluralism, Religion, and Moral Fairness of International Law, Vo. 3 Oktober 2014, Oxford Journal Law and Religion, hlm.1, http//m.ojlr. oxfordjournals.org/content/by/year, diakses 13April2016.

13 ...legal pluralism is as much a social fact as normative pluralism. It is important to distinguish between statelegal, legal polycentricity, autonomos and semi-auotonoms legal and social fact.........William Twinning, Normative and Legal Pluralism: A Global Perspective, Duke Journal of Comparative and International Law, Vol.20:473, 2010, hlm. 488-489, Duke Law University,http;// scholarshiplaw.duke.edu, diakses 13 April 2016.

14 Gordon R. Woodman, 'Mungkinkah Membuat Peta Hukum?', dalam Tim HuMa, eds., Pluralisme Hukum: Sebuah Pendekatan Interdisiplin, Penerbit Perkumpulan untuk Pembaharuan Hukum Berbasis Masyarakat dan Ekologis (HuMa), Jakarta, 2005, hlm.152.

15 John Griffiths, "Memahami Pluralisme Hukum, Sebuah Deskripsi Konseptual, dalam Tim HuMa, eds., Pluralisme Hukum: Sebuah Pendekatan Interdisiplin, Penerbit Perkumpulan untuk Pembaharuan Hukum Berbasis Masyarakat dan Ekologis (HuMa), Jakarta, 2005, hlm.74-75. John Griffiths mengemukakan pemahaman tentang pluralism hukum yang lemah mengacu pada ideology sentralisme hukum, yakni satu bagian kecil dari hukum negara, yang berlaku selama diperintahkan (secara implisit) oleh penguasa atau berdasarkan mandat kaedah dasar terhadap segolongan kecil masyarakat berdasarkan beberapa pertimbangan tertentu, yang dapat berupa faktor etnis, agama, nasionalitas atau geografis. dengan pengaturan kawasan tempat suci Pura Uluwatu melalui hukum adat Desa Adat Pecatu. Pertentangan tersebut tentunya harus dicarikan jalan keluarnya, salah satunya adalah dengan mengedepankan prinsip politik pluralism hukum dalam pengaturan kawasan tempat suci Pura Uluwatu.

\subsection{Politik Pluralisme Hukum Sebagai Potret Hukum Tidak Tunggal dalam Pengaturan Kawasan Tempat Suci Pura Uluwatu}

Terkait dengan pemaknaan hukum tidak tunggal dalam kajian pluralisme hukum, meminjam pemikiran segitiga Menski ${ }^{16}$, yang membagi 3 (tiga) sudut pandang yakni sudut pandang negara; masyarakat; serta moral, etika dan religi dalam bingkai pluralisme hukum. Dari Sudut Negara (berada disudut kiri segitiga), pengakuan negara terhadap hak atas tanah masyarakat di dasarkan pada terminology melindungi, walaupun negara mempunyai hak menguasai atas tanah di Indonesia.

Dari sudut masyarakat (berada di sudut kanan segitiga), pengakuan negara terhadap hak atas tanah masyarakat yang terdampak radius kawasan suci harus dilindungi pula berdasarkan realitas sosial. Hal ini sesuai dengan arahan Undang-Undang No 26 Tahun 2007 tentang penaatan ruang. ${ }^{17}$ Keadilan yang dituntut baik oleh masyarakat adat sebagai

16 Modifikasi dari Sukirno, Rekonstruksi Politik Hukum pengakuan Negara terhadap Hak Ulayat (Studi Pengakuan dan Perlindungan Eksistensi Hak Ulayat Masyarakat Hukum Adat Baduy dari Hegemoni Negara), Disertasi, Program Doktor Ilmu Hukum, UNDIP Semarang, 2014, hlm. 378. Lihat juga. Werner Mensky, Comparative Law In A Global Context, The Legal System IN Asia and Africa, Cambrige University Press, United Kingdom, 2006, hlm,186-188. 17 Pada Pasal 7 ayat (1) menyatakan, Negara menyelenggarakan penataan ruang untuk sebesarbesar kemakmuran rakyat, selanjutnya ayat (2) Dalam melaksanakan tugas sebagaimana dimaksud pada ayat (1), negara memberikan kewenangan penyelenggaraan penataan ruang kepada Pemerintah dan pemerintah daerah, dan ayat (3) Penyelenggaraan penataan ruang sebagaimana dimaksud pada ayat (2) dilakukan dengan tetap menghormati hak yang dimiliki orang sesuai dengan ketentuan peraturan perundang-undangan. Kemudian dalam penjelasan Ayat (3) Hak yang dimiliki orang mencakup pula hak yang dimiliki masyarakat adat sesuai dengan ketentuan peraturan perundangundangan. Jelas ini berbeda dengan apa yang di atur oleh Perda RTRWP Bali yang mengabaikan hak yang dimiliki masyarakat adat dan hak yang dimiliki orang dalam menata ruang dan wilayah di Bali. 
kesatuan hukum adat yang punya hukum mengenai kawasan suci Pura Uluwatu atau sebagai masyarakat yang mempunyai hak atas tanah selayaknya dengan pemerintah terjadi suatu tawar-menawar untuk mencapai keadilan tersebut. Hal ini sesuai dengan pendapat John Rawls ${ }^{18}$, yang menyatakan Prinsip keadilan adalah hasil dari persetujuan dan tawarmenawar yang fair. Karena dengan adanya situasi posisi itu, relasi semua orang menjadi simetri, maka situasi awal ini adalah fair antar individu sebagai person moral, yakni sebagai makhluk rasional dengan tujuan dan kemampuan mereka mengenali rasa keadilan. Kesetaraan posisi antara masyarakat sebagai kesatuan masyarakat adat dan sebagai individu dengan negara dalam menentukan radius kawasan suci Pura sangat diperlukan untuk mencapai keadilan.

Dari sudut pandang moral, etika dan religi (berada di sudut bagian atas segitiga), negara (pemerintah daerah) dalam membentuk peraturan perundang-undangan, harus mampu memadukan etika untuk menghargai perbedaan persepsi dengan masyarakat mengenai radius kawasan suci Pura, berdasarkan keyakinan yang mereka anut yang secara moral dengan menerapkan keadilan sosial yang transisional (adanya perbedaan antara satu tempat dengan yang lainnya). Bentuk kebijakan apapun dari pemerintah menyangkut langsung atau tidak langsung dengan masyarakat adat harus dikomunikasikan hingga kebijakan dapat diterima tanpa ada pihak yang dirugikan. ${ }^{19}$

Saling melengkapinya antara, hukum adat (kearifan lokal) dan hukum negara dalam

18 John Rawls, A Theory of Justice, The Belknap Press Of Harvard University Press, Cambridge, Massachusetts, London, England, 2005, hlm.11-12.

19 Agung Basuki Prasetyo, Pengakuan Hak Ulayat Masyarakat Hukum Adat (Antara Regulasi dan Implementasi), dalam Jurnal Masalah-Masalah Hukum, Fakultas Hukum, Universitas Diponegoro Semarang, Vol. 36, No. 2 April-Juni 2007, hlm.153. menata hukum tata ruang yang menyangkut radius kawasan suci Pura Uluwatu di Bali dapat diistilahkan sebagai suatu simbiosis hukum tata ruang di Bali. Dalam artian lain, hukum tata ruang di bangun oleh beberapa jenis hukum yang berbeda yang kemudian berinteraksi saling melengkapi antara satu dengan yang lainnya untuk kemudian menjadi suatu kekuatan yang ideal dalam menata tata ruang kawasan suci Pura Uluwatu di Bali. Hal itu diperlukan untuk menghindari terjadinya pertarungan politik hukum negara dan politik kebudayaan, akibat adanya terjadi tarik menarik antara kepentingan negara (pemda) melalui instrument hukumnya dengan desa adat yang memiliki karakter hukum desa, kala, patra, desa mawacara. ${ }^{20}$

\section{PENUTUP}

Berdasarkan pembahasan di atas, terdapat 2 (dua) simpulan yang dapat disampaikan, antara lain:

1. Bahwa perlunya politik pluralisme hukum dalam pengaturan kawasan tempat suci Pura Uluwatu di Bali didasari oleh keberadaan hukum yang tidak tunggal di Bali yang mengatur tentang kawasan suci Pura Uluwatu. Tidak tunggal dalam artian selain adanya hukum Negara dalam bentuk produk hukum daerah tentang tata ruang di Bali, juga terdapat unsur nilai-nilai moral, etika, dan agama, serta hukum yang ada di masyarakat Desa Adat Pecatu ditambah lagi kemudian ada nilai hak asasi manusia di dalamnya.

2. Model politik pluralisme hukum sangat relevan diadopsi dalam pengaturan kawasan tempat suci Pura Uluwatu di Bali.

20 I Wayan Wesna Astara, Pertarungan Politik Hukum negara dan Politik Kebudayaan, Otonomisasi Desa Adat diBali, Udayana University Press, Denpasar, 2010, hlm.4. 


\section{DAFTAR PUSTAKA}

Astara, I Wayan Wesna, 2010, Pertarungan Politik Hukum negara dan Politik Kebudayaan, Otonomisasi Desa Adat di Bali, Denpasar: Udayana University Press.

D.fry, James, 2014, Pluralism, Religion, and Moral Fairness of International Law, Vo. 3 Oktober 2014, Oxford Journal.

Freidmann, Lawrence M., 2009, Sistem Hukum Perspektif Ilmu Sosial, Bandung: Nusa Media, Bandung.

Irianto, Sulistyowati, 2011, Akses Keadilan dan Migrasi Global, Kisah Perempuan Indonesia Pekerja Domesik di Uni Emirat Arab, Jakarta: Yayasan Pustaka Obor.

Kennedy, David, 2013, Leiden Journal of International Law 26, pp. 7-48 C_Foundation of the Leiden Journal of International Law, 2013, International Legal Theory, Law and the Political Economy of the World http://journals.cambridge.org, acsess on 14 April 2016.

Marbun, S.F., dkk, 2004, Dimensi-dimensi Pemikiran Hukum Administrasi Negara, Yogyakarta: UII Press.

McCarthy, Thomas, 1982, The Critical Theory of Jurgen Habermas, Massachusetts: MIT Press.

Menski, Werner, 2008, Perbandingan Hukum dalam Konteks Global, Sistem Eropa, Asia, dan Afrika, Bandung: Nusa Media.

Menski, Werner, 2015, Flying Kites In A Global Sky: New Models Of Jurisprudence, http://www. sociolegalreview.com/wp-content/uploads/2015/12/flying-Kites-In-A-Global-SkyNew-Models-of-Jurisprudence-Werner-Mensky.pdf.

Nurhadi, 2011, Teori Kritis Jurgen Habermas, BAntul: Kreasi Wacana, Bantul.

Prasetyo, Agung Basuki, 2007, Pengakuan Hak Ulayat Masyarakat Hukum Adat (Antara Regulasi dan Implementasi), dalam Jurnal Masalah-Masalah Hukum, Fakultas Hukum, Universitas Diponegoro Semarang, Vol. 36, No. 2 April-Juni 2007.

Rawls, John, 2005, A Theory of Justice, The Belknap Press Of Harvard University Press, Cambridge, England: Massachusetts.

Said, M.Mas'ud, 2007, Birokrasi Di Negara Birokratis, Malang: UMM Press.

Samekto, FX Adji, 2008, Justice Not For All, Kritik terhadap Hukum Modern dalam Perspektif Studi Hukum Kritis, Yogyakarta: Genta Press.

Sukirno, 2014, Rekonstruksi Politik Hukum pengakuan Negara terhadap Hak Ulayat (Studi Pengakuan dan Perlindungan Eksistensi Hak Ulayat Masyarakat Hukum Adat Baduy dari Hegemoni Negara), Semarang: Disertasi PDIH UNDIP.

Tim HuMa, eds., 2005, Pluralisme Hukum: Sebuah Pendekatan Interdisiplin, Jakarta: Penerbit Perkumpulan untuk Pembaharuan Hukum Berbasis Masyarakat dan Ekologis (HuMa).

Twinning, William, 2010, Normative and Legal Pluralism: A Global Perspective, Duke Journal of Comparative and International Law, Vol.20:473.

Yusriyadi, 2009, Tebaran Pemikiran Kritis Hukum dan Masyarakat, Malang: Surya Pena 